\title{
Senam Pagi umtuk Membangun Motivasi Belajar Siswa Tunagrahita
}

\author{
Azizah Rahmawati ${ }^{1}$, Abdul Huda ${ }^{2}$ \\ ${ }^{1}$ SLB YPTB Malang \\ ${ }^{2}$ Universitas Negeri Malang \\ E-mail: Rachma_egaliter69@yahoo.com
}

\begin{abstract}
Abstrak: Kemampuan intlektual yang bisa berpengaruh terhadap kemampuan sosialnya, seperti interaksi yang tidak terarah, sehingga penanganan khusus ataupun upaya penyesuaian didalam menentukan strategi dan perencanan mengajarnya sangat diperlukan. Tujuan penelitian (1) Mendeskripsikan pelaksanaan senam pagi. (2) Mendeskripsikan hambatan implementasi senam pagi, (3) Mendeskripsikan solusi mengatasi hambatan implementasi senam pagi. (4) Mendeskripsikan dampak senam pagi terhadap motivasi belajar siswa. Penelitian ini menggunakan metode penelitian kualitatif dengan pendekatan studi kasus. Dari hasil teknik pengumpulan data, analisis data dan pengecekan keabsahan temuan yang dilakukan peneliti, menunjukan bahwasannya dalam implementasi kegiatan senam pagi di sekolah didapati (1) Program: penyampiaan tujuan, penentuan sasaran, penanggung jawaban kegiatan, pemilihan bentuk kegiatan senam, pelaksanan dan pengadaan evaluasi. (2) Pelaksanaan: persiapan kegiatan senam, pelaksanaan kegiatan senam, hasil senam pagi dalam pembelajaran dan evaluasi. (3) Hambatan: kondisi siswa dan sarpras. (4) Solusi mengatasi hambatan berupa: pendekatan afeksi dan cara alternatif. (5) Dampak: ketertarikan, kebugaran, kemampuan motorik dan prestasi.
\end{abstract}

Kata Kunci : Senam Pagi, Motivasi Belajar, Tunagrahita Mampu Didik.

\begin{abstract}
Abstrak : Intellectual capabilities that can affect their social capabilities, such as non-directional interaction, so that special handling or adjustment efforts in determining the strategy and planning of teaching is needed. The purpose of research (1) Describe the implementation of morning gymnastics. (2) Describe the obstacles of implementation of morning gymnastic, (3) Describe solution to overcome obstacle of morning gymnastics implementation to build student's learning motivation. (4) Describe the impact of morning gymnastics on student learning motivation. From data results collection techniques, data analysis and checking the validity of findings conducted by researchers, showed that in the implementation of morning gymnastic activities at school founded (1) program: goals delivery, targeting, responsibility for activities, Gymnastics activities, implementation and evaluation procurement. (2) implementation: preparation of gymnastics activities, the implementation of gymnastics activities, the results of morning exercises in learning and evaluation. (3) Barriers: students' condition and infrastructure. (4) Solutions: Approach affection and alternative ways (5) Impact: Interest, fitness, motor skills and achievement.
\end{abstract}

Keywords: Gymnastics, Motivation Learning, Intellectual Disabilities

Pembelajaran yang aktif, kreatif dan menyenangkan akan tercipta apabila motivasi belajar yang dimiliki siswa bisa terbangun, demikian ini dikarenakan kesiapan belajar siswa akan mendorong kesadaran didalam upayanya memperoleh ilmu, sebagaimana tujuan dan harapan yang dimiliki. Hal ini bertepatan dengan pendapat Sutikno (dalam Muhardian, 2007) bahwasannya " Motivasi berprestasi (achievement motivation) mempunyai kontribusi sampai 64 persen terhadap prestasi belajar“. Diasumsikan bahwa jika siswa mampu mengetahui benar pentingnya belajar bagi diri, motivasi belajar yang dimilikinya akan menjadi tinggi, sehubungan dengan itu jika dilihat dalam orientasinya bagi anak berkebutuhan khusus terutama tunagrahita, tentu saja upaya membangun motivasi belajar dirasa lebih besar kendalanya dibandingkan dengan anak reguler, hal ini dikarenakan mereka cendrung memiliki hambatan didalam kemampuan intlektual yang bisa berpengaruh terhadap kemampuan sosialnya, seperti interaksi yang tidak terarah, sehingga penanganan khusus ataupun upaya penyesuaian didalam menentukan strategi dan perencanan mengajarnya sangat diperlukan, sebagaimana pendapat dari Suryani (2010) "Anak tunagrahita memiliki intelegensi antara 50-70, sehingga prestasi akademik dan kemampuan adaptasi sosialnya terhambat oleh kondisi tersebut". Anak tunagrahita mampu didik merupakan salah satu kategori anak tunagrahita ringan yang kemampuan belajarnya masih dapat dikembangkan walaupun tidak sekaya anak regular, kemampuan yang bisa dikembangkan bagi anak tunagrahita mampu didik diantaranya, yaitu: “ (1) membaca, menulis, mengeja, dan berhitung; (2) menyesuaikan diri dan tidak menggantungkan diri pada orang lain; (3) keterampilan yang sederhana untuk kepentingan kerja dikemudian hari" (Liyana, Muhariati \& Rusilanti, 2014).

Motivasi belajar siswa tunagrahita mampu didik 
di sebuah sekolah menunjukkan hasil yang cukup memuaskan, terbukti pada nilai mata pelajaran, kesiapan dan sikap peserta didik dalam menekuni kegiatan pembelajaran sudah mencapai diatas nilai rata-rata yang telah ditentukan oleh pihak sekolah. Demikian ini dipengaruhi oleh kesadaran sekolah memfasilitasi dalam upaya membangun motivasi belajar bagi peserta didik sudah cukup baik, yakni dengan menerapkan kegiatan olah raga senam pagi bersama, uniknya kegiatan senam ini diterapkan secara rutin setiap hari kecuali hari jum'at sebelum memulai kegiatan pembelajar. Sjarifuddin (1980) mengemukakan pendapatnya mengenai keterkaitan penerapan olahraga di dalam kehidupan, "Bila ingin selalu tetap sehat, segar dan masa hidup yang lebih kuat, hendaknya ada keseimbangan diantara kerja otak dengan kerja fisik (jasmani)", penjelasan tersebut menunjukan adanya manfaat dari olah raga, bukan sekedar upaya membangun kesehatan dan ketangkasan jasmani, melainkan bisa berdampak didalam membangun kesehatan rohani dan fikiran yang merupakan sebuah lokomotor motivasi. Selain itu fungsi olahraga sejalan dengan Pradipta (2017) Dalam rangka pencegahan permasalahan baru dan meningkatkan fungsi anggota gerak yang mengalami kekakuan.

Pemberian kegiatan senam disini harus memperhatikan kebutuhan siswa, yakni harus sesuai dengan kemampuan, minat dan potensi untuk mengembangkan kesanggupannya. Selama ini, dalam memberikan atau memilihkan peragaan senam pagi, guru kurang memperhatikan kebutuhan, minat dan potensi siswa. Mujianto (2015) menyampaikan “ Permasalahan tersebut juga dipengaruhi dengan pembelajaran penjas karena kurang didukung oleh tingkat kreativitas dan inovatif dalam pengembangan model pembelajaran sedangkan fasilitas sarana dan prasarana cukup memadai". jika demikian bukan tidak mungkin siswa akan menjadi sulit mengikuti dan mudah jenuh, oleh karnanya sangat perlu diperhatikan bentuk penyesuaiannya, yang dalam hal ini adalah upaya modifikasi, sebagaiman hakikat didalam pengetahuan penjas adaptif. Abdurrahman (dalam Ragil, 2009) menjelaskan " pendidikan jasmani adaptif ialah modifikasi dari bentuk pendidikan jasmani, guna untuk mempertemukan kebutuhan- kebutuhan anak yang menyandang ketunaan". Beberapa bentuk upaya modifikasi dalam senam bisa difokuskan dalam hal pemilihan gerakan dan musik yang sederhana, menarik dan ceria juga tidak lupa diikuti dengan penerapan peragaan senam yang bervariatif (berganti-ganti video senam / senam yang ditampilkan) di setiap harinya.

\section{METODE}

Penelitian ini menggunakan metode kualitatif dengan pendekatan studi kasus. Pemilihan metode ini disebabkan adanya kesesuaian dengan pendapat
Sugiyono (2009) bahwa "Metode penelitian kualitatif adalah metode penelitian yang berlandaskan pada filsafat postpositivisme, digunakan untuk meneliti pada kondisi obyek yang alamiah, (sebagai lawannya adalah eksperimen) dimana peneliti adalah sebagai instrumen kunci, pengambilan sampel sumber data dilakukan secara purposive dan snowball. Teknik pengumpulan dengan trianggulasi (gabungan), analisa data bersifat induktif/kualitatif, dan hasil penelitian kualitatif lebih menekankan makna daripada generalisi”. Sehingga untuk mendapatkan gambaran mengenai proses pelaksanaan senam pagi ditiap harinya dalam upaya membangun motivasi belajar anak tunagrahita mampu didik yang hanya diterapkan di salah satu sebuah sekolah, dalam hal ini berarti peristiwa yang diteliti ini merupakan sebuah peristiwa khusus atau unik dalam suatu waktu/tempat tertentu yang pengamatannya tidak bisa diukur dengan angka ataupun hanya disimpulkan melalui tabulasi numerik, namun diperlukan rincian secara tabulasi narasi dan gamblang untuk menemukan tujuan penelitian sehingga model penelitian kualitatif dengan pendekatan secara studi kasus ini dipilih, hal ini selaras dengan yang dikemukakan oleh.

Creswell (1998) bahwa," Apabila akan memilih studi untuk suatu kasus, dapat dipilih dari beberapa program studi atau sebuah program studi dengan menggunakan berbagai sumber informasi yang meliputi: observasi, wawancara, materi audiovisual, dokumentasi dan laporan. Konteks kasus dapat "mensituasikan" kasus di dalam settingnya. Sedangkan fokus di dalam suatu kasus dapat dilihat dari keunikannya, memerlukan suatu studi (studi kasus intrinsik) atau dapat pula menjadi suatu isu (isu-isu) dengan menggunakan kasus sebagai instrumen untuk menggambarkan isu tersebut (studi kasus instrumental).

Teknik pengumpulan data dalam penelitian ini yakni dengan menggunakan beberapa teknik pengumpulan data agar data yang didapatkan semakin lengkap dan kaya. "Dalam penelitian kualitatif data diperoleh dari berbagai sumber, dengan menggunakan teknik pengumpulan data yang bermacam-macam (Tringulasi), dan dilakukan secara terus menerus sampai datanya jenuh" (Sugiyono, 2009). Yang termasuk didalam kategori pengumpulan data tersebut dalam menggali informasi penelitian tentang implementasi senam pagi dalam membangun motivasi belajar siswa tunagrahita mampu didik, adalah sebagai berikut.

\section{Observasi}

Nasution (dalam Sugiyono, 1988) mengemukakan bahwa, " Observasi adalah dasar semua ilmu pengetahuan. Para ilmuwan hanya dapat bekerja berasarkan data, yaitu fakta mengenai dunia kenyataan yang diperoleh melalui observasi”. Sehingga observasi dapat diartikan sebagai upaya penyelidikan yang dilakukan secara sistematik dan sengaja dengan pengamatan terhadap peristiwa yang ingin dianalisa atau diketahui. 


\section{Gambar 1 Bagan Teknik Analisis Data Interaktif}

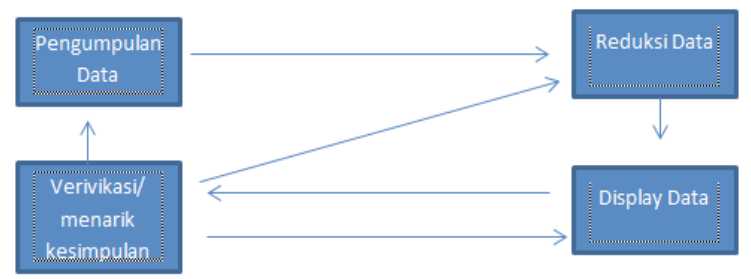

Dalam penelitian ini observasi yang digunakan adalah tipe Observasi berpartisipasi (Participant observation), dengan model partisipan aktif (Active participant), yang melewati tahap-tahap observasi yakni, Observasi deskriptif, terfokus, dan terseleksi.

\section{Wawancara}

Merupakan sebuah upaya didalam menggali informasi secara langsung dalam konteks komuikasi dua arah kepada satu orang ataupu kelompok, diharapkan dengan cara tersebut akan diperoleh hasil yang autentic karna langsung ke narasumbernya. Esterberg (dalam Sugiyono, 2002) mengemukakan defenisi wawancara atau interview sebagai berikut. "Interview adalah merupakan pertemuan dua orang untuk bertukar informasi dan ide melalui tanya jawab, sehingga dapat dikonstruksikan makna dalam suatu topik tertentu".

Penelitian ini Akan menggunakan wawancara secara mendalam, yang disebut in depth interview dengan jenis wawancara semi terstruktur (semi tructure interview). "Tujuan dari wawancara jenis ini adalah untuk menemukan permasalahan secara lebih terbuka, di mana pihak yang diajak wawancara dimintai pendapat, dan ide-idenya."(Sugiyono, 2014), sehingga jenis wawancara ini dirasa akan lebih sesuai dengan penelitian ini, guna mendapatkan informasi atau sumber data secara meluas.

\section{Dokumentasi}

Metode dokumentasi ialah cara mengumpulkan data tak langsung dengan arsip, catatan dan hasil rekam sebagai pelengkap informasi dari sumber terdahulu. Sugiyono (2009) berpendapat “ Hasil penelitian dari observasi atau wawancara, akan lebih kredibel/ dapat dipercaya kalau didukung oleh sejarah pribadi kehidupan dimasa kecil, di sekolah, di tempat kerja, di masyarakat, dan autubiografi". Dokumentasi dalam penelitian ini adalah berupa bukti foto, video dan rekaman selama observasi dan wawancara dalam kegiatan senam, kegiatan belajar mengajar, kegiatan sehari-hari, sarana prasarana ataupun arsip sekolah, berkas profil sekolah,RPP, jurnal, raport dan data program.

Analisis data dalam penelitian kualitatif ini dilakukan dalam proses yang interaktif dengan metode yang bersifat induktif. "suatu analisa berdasarkan data yang diperoleh, selanjutnya dikembangkan pola hubungan tertentu atau menjadi hipotesis" (Sugiyono, 2009). Proses analisis data memiliki komponenkomponen utama yang harus benar-benar dipahami. Komponen tersebut adalah reduksi data, kajian data, dan penarikan kesimpulan atau verifikasi.

Penjelasannya sebagai berikut. Setelah peneliti mengadakan pengumpulan data ditahap pertama, maka peneliti melakukan antisipatory sebelum melakukan reduksi data sebagai tahap ke dua, kemudian masuk direduksi data di sini data dirangkum untuk mencari pola dan temanya agar gambaran yang diberi menjadi lebih jelas, setelah data direduksi maka masuk pada display data dalam bentuk penyajian data berupa tabel, grafik dan sejenisnya agar tersusun dalam pola hubungan, peneliti harus intens di dalam menguji apa yang telah ditemukan pada saat memasuki lapangan yang masih bersifat hipotetik itu berkembang tidak, jika hipotesis tersebut selalu didukung data maka hipotesis tersebut terbukti sehingga bisa berkembang menjadi teori yang grounded tahap ketiga adalah verifikasi atau penarikan kesimpulan. Kesimpulan data di sini masih bersifat sementara dan bisa berubah jika tidak ditemukan bukti-buktinya yang kuat sehingga ada dua kemungkinan kembali bisa pada tahap display data ataupun tahap reduksi kembali, tetapi apabila kesimpulan awal tadi bisa diterima dengan bukti-bukti data yang valid dan tetap konsisten saat kembali kelapangan untuk mengumpulkan data maka kesimpulan penelitian tersebut bisa dikatakan kredibel sehingga bisa menjawab rumusan masalah yang telah dirumuskan di awal.

Pengecekan kebsahan dalam penelitian ini hanya membutuhkan sampai tahap credibility saja, sehingga sesuai dengan kebutuhan. Pada tahap pengecekan keabsahan temuan credibelity ini, di dalamnya memiliki pedoman proses yakni, memperpanjang pengamatan, menguatkan ketekunan, triangulasi, analisa kasus negatif, menggunakan bahan refrensi, dan mengadakan member cek. Triangulasi cara digunakan sebagai pengecekan data dari berbagai cara. Bentuk cara triangulasi tersebut ada cara teknik, sumber ataupun waktu.

\section{HASIL dan PEMBAHASAN}

\section{Hasil}

Pelaksanaan senam pagi, Sebelum kegiatan dilaksanakan guru dan murid mempersiapkan diri, sarana dan prasarananya. Masing-masing jenis kegiatan senam tersebut dilaksanakan setiap hari di pagi hari sebelum memulai pembelajaran dengan

Kemudian dari tahap pelaksanaan, ditetapkanlah bentuk evaluasi program kegaiatan senam pagi. Sebagaimana yang disampaikan oleh Bu Sari mengenai evaluasi dari kegiatan senam pagi ini. 
Tabel 1. Penanggung Jawab Program Kegiatan Senam Pagi

\begin{tabular}{lll}
\hline No & Jenis Kegiatan & Penanggung Jawab \\
\hline 1 & $\begin{array}{l}\text { Pembentuk tim } \\
\text { program senam }\end{array}$ & Kepala Sekolah \\
2 & Pelaksana & Tim Guru \\
3 & Pengadaan Sarpras & Kepala Sekolah dan \\
& & Tim Guru \\
4 & Pendamping & Semua \\
\hline
\end{tabular}

Tabel 2. Evaluasi Program Kegiatan Senam Pagi

\begin{tabular}{|c|c|c|}
\hline No & $\begin{array}{l}\text { Jenis } \\
\text { Evaluasi }\end{array}$ & Pelaksanaan \\
\hline 1 & Evaluasi input & $\begin{array}{l}\text { Dilakukan pada tahap } \\
\text { persiapan, } \\
\text { jumlah } \\
\text { perlengkapan } \\
\text { diperlukan. }\end{array}$ \\
\hline 2 & $\begin{array}{l}\text { Evaluasi } \\
\text { proses }\end{array}$ & $\begin{array}{l}\text { Kelancaran acara } \\
\text { ketepatan waktu dan } \\
\text { ketepatan pembagian } \\
\text { tugas), jumlah pesrta } \\
\text { yang hadir dan } \\
\text { antusiasme peserta. }\end{array}$ \\
\hline 3 & $\begin{array}{l}\text { Evaluasi } \\
\text { Outcome }\end{array}$ & $\begin{array}{l}\text { Hasil jangka panjang } \\
\text { dari kegiatan }\end{array}$ \\
\hline
\end{tabular}

Tabel 3. Indikator Penilaian Keberhasilan Evaluasi Kegiatan Senam

\begin{tabular}{ll}
\hline No & Indikator Penilaian Keberhasilan \\
\hline 1 & Antusiasme dari peserta \\
2 & Keaktifan peserta \\
3 & Peningkatan semangat siswa \\
4 & Hasil perkembangan belajar siswa \\
\hline
\end{tabular}

Gambar 2 Bagan Pelaksanaan Senam Pagi Dalam Upaya Membangun Motivasi Belajar Siswa Tunagrahita Mampu Didik di SMPLB Putra Jaya Malang.

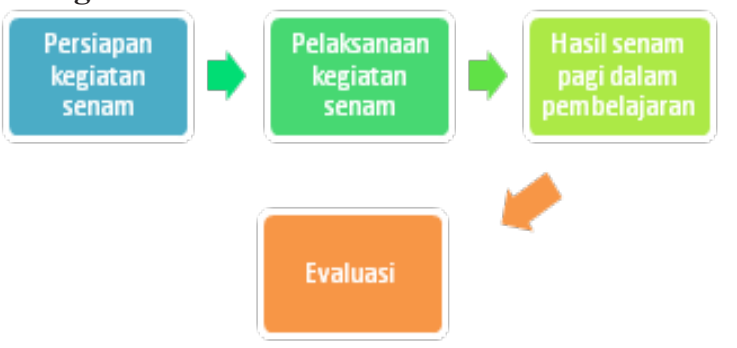

Jenis evaluasi yang terdapat dalam evaluasi program kegiatan senam pagi serta penjelasan pelaksanaannya terdapat dalam paparan pada tabel 2 .

Evaluasi kegiatan ini dilaksanakan oleh seluruh pihak sekolah di akhir kegiatan dengan melihat indikator penyesuaian sebagai penilaian keberhasilan program kegiatan senam pagi, dalam tabel 3 akan dimuat beberapa indikator yang termasuk didalamnya.

Sebelum kegiatan dilaksanakan guru dan murid mempersiapkan diri, sarana dan prasarananya. Sarana dan prasarana yang tersedia terbilang memadai. Masing-masing jenis kegiatan senam tersebut dilaksanakan setiap hari di pagi hari sebelum memulai pembelajaran dengan cara menggilir senam, namun untuk menyesuaikan kondisi siswa terkadang senam tersebut tidak digilir atau di ganti di hari berikutnya. Dalam pelaksanaan kegiatan senam sendiri terdiri dari tahap permulaan, pemanasan dan pendinginan,selain itu olah tubuh di dalam senam banyak mengandung edukatif. Hasil dari kegiatan senam pagi terhadap proses belajar adalah, seperti beberapa kegiatan di lingkungan sekolah dalam hal pembelajaran (akademis dan non akademis) dan kemampuan berinteraksi sosial terlaksana dengan lancar dan baik, keseluruhan ini terlihat dari motivasi mereka yang cukup tinggi akibat kesiapan siswa itu sendiri setelah melalui kegiatan senam pagi sebelumnya. Selanjutnya diakhir kegiatan senam guru juga mengadakan evaluasi guna mengukur keberhasilan program tersebut.

Hambatan implementasi senam pagi bagi siswa tunagrahita mampu didik disekolah meliputi: 1) Kondisi siwa, hal ini bersifat internal dan permanen, selanjutnya 2) Kondisi sarpras, salah satunya adalah kendala mati lampu, kendala ini bersifat eksternal dan tidak permanen tetapi insidennya bisa terjadi secara tak terduga. Solusi dari hambatan pelaksanaan senam pagi dapat dijabarkan seperti ini. Pemberian solusi tindakan afeksi didalam pendekatan itu berupa upaya untuk membujuk, membantu dan menyesuaikan dengan kendala kondisi siswa, selanjutnya pemberian cara alternatif yakni melakukan senam dengan cara manual, bisa dari mengikuti peragaan guru ataupun menyetel musiknya lewat hp hal ini diterapkan ketika mengalami kendala mati lampu.

Dampak dari kegiatan terebut diantaranya: Siswa merasa tertarik, berupa senang dengan kegiatan tersebut, terdapat peningkatan prestasi belajar bagi siswa dan sekolah, Kemampuan motorik atau aktifitas fisik menjadi lebih bagus, kebugaran dan kesehatn tubuh lebih baik, sehingga keseluruhan point tersebut sangat berpengaruh didalam peningkatn motivasi mengikuti kegiatan pembelajaran.

\section{Pembahasan}

SMPLB ini merupakan salah satu sekolah sebagai lembaga pendidikan pertama menengah pert bagi anak-anak berkebutuhan khusus, yang 
memperhatikan upaya pembangunan motivasi belajar siswanya berupa aktivitas mengawali kegiatan pembelajaran. Terbukti dengan sekolah yang menerapkan kegiatan senam pagi setiap hari, beserta penyusunan programnya dan banyaknya pemilihan jenis-jenis senam yang telah disesuaikan dengan kebutuhan peserta didik, sehingga didapati jenis-jenis senam yang diterapkan di salah satu sekolah SMPLB ini, diantaranya adalah senam Sehat Ceria Anak Indonesia, senam Ayo Baris, senam Gemofamire dan senam Pinguin dimana keseluruhan senam tersebut merupakan bentuk senam pagi berirama. Purnama (dalam Mahendra, 2000) "senam dalam Bahasa Indonesia sebagai salah satu cabang olah raga merupakan terjemahan langsung dari gymnastic", sehingga senam pagi merupakan sebuah cabang olah raga ringan yang dilakukan setiap pagi dimana sangat bermanfaat bagi kebugaran tubuh untuk mengawali sebuah aktivitas. Dengan adanya kegiatan senam pagi ini diharapkan peserta didik tunagrahita mampu didik dapat memacu motivasi belajarnya di sekolah baik secara akademis maupun non akademis.

Perencanaan sebagai persiapan dimulai dari proses perancangan program kegiatan, pelaksanaan sampai pengadaan evaluasi kegiatan tersebut diantaranyamenyusun(penyampiantujuan, penentuan sasaran, penanggung jawaban kegiatan,pemilihan bentuk kegiatan senam, pelaksanan dan pengadaan evaluasi). Perencanaan ditentukan dalam sebuah rapat oleh pihak sekolah dengan menyertakan peserta didik sebagai obyek pengamatan atau sasaran kegiatan tersebut dengan mengacu pada indikator keberhasilan program kegiatan senam. hal-hal yang tersusun di dalam rencana program tersebut akan dijadikan acuan didalam pelaksanaan kegiatan senam sehingga dapat menyesuaikan kebutuhan peserta didik dan berjalan sesuai tujuan sekolah.

Selama kegiatan senam pagi bersama, guru beserta murid mempersiapkan hal penunjang dan pelaksanaan kegiatan secara koperatif, hal ini guna menunjang efesiensi kelancaran dan efektifitas di dalam memberikan pembelajran bina diri bagi pihak sekolah dan peserta didik. Menurut Anggraeni (dalam Stahl, 2011) menjelaskan bahwa " Model pembelajaran kooperatif menenempatkan siswa sebagai bagian dari suatu sistem kerja sama dalam mencapai suatu hasil yang optimal dalam belajar ".

Pelaksanaan Program kegiatan senam pagi di salah satu sekolah SMPLB sesuai dengan rutinitas yang tercantum didalam jurnal dan RPP, sehingga dalam pelaksanaanya berbeda dari kegiatan senam yang diterapkan di sekolah lain, karna di sekolah ini diadakan setiap hari kecuali hari jum'at. Dalam proses pelaksanaan kegiatan senam pagi biasanya akan diadakakan persiapan dari guru dan siswa, seperti mempersiapkan barisan, mempersiapkan sara prasarana dan mempersiapkan senam yang akan diputar. Untuk senamnya sendiri merupakan bentuk senam pagi berirama tersusun dari gerakan yang edukatif, menarik dan mudah dimana terdiri dari tahap permulaan, pemanasan dan pendinginan sehingga manfaat dari senam tersebut dapat terdistibusi di dalam tubuh dengan baik.

Selama berlangsungnya kegiatan senam siswa diberi kesempatan oleh guru didalam mengembangkan kemampuan eksplorasinya, sehingga terlihat di beberapa sesi siswa tampak bermain-main dengan kegiatannya selama senam, bagi guru pembelajaran untuk anak berkebutuhan khusus itu lebih sesuai dengan menerapakan model belajar sambil bermain karna dari sana sisw aselain mengembangkan intlektualnya juga mengembangkan kemampuan interaksi dan kreatifitasnya.Untuk pelaksanaan kegiatan belajar sendiri terlihat berjalan dengan baik. Hal ini terlihat disaat siswa mengikuti berbagai pembelajaran yang bersifat akademis maupun non akademis, seperti siswa nampak termotivasi di dalam pembelajarannya seperti menyimak dan melaksanakan tugas dengan baik, durasi yang dibutuhkan didalam menyelesaikan tugas tidak lama, Prestasinya dibeberapa perlombaan,( salah satunya kemarin salsa mendapat juara 3 untuk perlombaan lari FL2SN turnamen April 2017), mengetahui tujuan didalam belajar sesuai pemahamannya, dan ketabahan atau kerajinan didalam mengikuti kegiatan pembelajaran.

Dari hasilwawancara, observasi dan dokumentasi yang di lakukan peneliti menunjukan bahwasannya sejauh ini pelaksanaan dan keberlangsungan kegiatan senam pagi di SMPLB Putra Jaya malang berlangsung dengan baik dan lancar hal ini selain karna ketepatan didalam perancangan programnya, ketertarikan peserta didik, peran serta guru yang berkontribusi juga hal-hal yang mendukung seperti sarana prasarana yang disediakan sekolah cukup memadai. Sehingga didapat teoritisasi data yakni motivasi belajar siswa tunagrahita mampu didik dapat ditingkatkan dengan penerapan kegiatan senam setiap hari sebelum memulai pembelajaran.

Dalam Pelaksanaan program kegiatan senam pagi, sekolah pastinya menemui beberapa hambatan, namun sejauh ini tidak begitu menjadi penghalang didalam berlangsungnya kegiatan tersebut, terlebih ketika kegiatan tersebut sudah menjadi kebutuhan dan kesadaran bagi seluruh anggota sekolah, sehingga kegiatan senam pagi tetap ditekuni didalam keberlangsungan kegiatannya yang secara rutin tersebut. Hambatan-hambatan yang selama ini dihadapai adalah: 1) Kondisi siwa hal ini bersifat internal dan permanen yakni permasalahan kesulitan dalam menirukan gerakan, mood, dan perbedaan selera, selanjutnya 2) Kondisi sarpras, kendala ini bersifat eksternal dan tidak permanen tetapi insidennya bisa terjadi secara tak terduga, salah satunya adalah kendala mati lampu. 
Dalam mengatasi sejumlah hambatan yang ditemukan selama proses pelaksanaan kegiatan senam pagi khususnya bagi siswa tunagrahita mampu didik di SMPLB tersebut, pihak sekolah yang terdiri dari kepala sekolah dan tim guru merencanakan sekaligus mengupayakan beberapa solusi dan alternatifnya. Pemberian solusi bagi hambatan kondisi anak, yaitu guru memberikan tindakan afeksi didalam pendekatan, ini berupa upaya untuk membujuk, membantu dan menyesuaikan dengan kendala kondisi siswa, selanjutnya pemberian solusi bagi hambatan kondisi sarpras, pihak sekolah dan siswa memiliki cara alternatif yakni melakukan senam dengan cara manual, bisa dari mengikuti peragaan guru ataupun menyetel musiknya lewat hp hal ini diterapkan ketika mengalami kendala mati lampu.

Keseluruhan itu dapat teratasi berkat dari solusi yang lebih penting dan mendasar, yakni kesadaran dan menjadikannya sebagai sebuah kebiasaan yang ditanam oleh seluruh anggota sekolah, mulai dari kepala sekolah, guru, siswa dan staf disana. Untuk keberlangsungan dan dukungan selebihnya, pihak sekolah pun tetap intens didalam menjalin komunikasi kepada para wali murid, mengenai berbagai hal yang berhubungan dengan kegiatan sekolah, selain itu pihak sekolah telah mengupayakan pengadaan program tersebut dengan sebaik-baiknya, mulai dari perencanaan, pelaksanaan sampai evaluasi guna bisa memberi manfaat yang bisa dirasa bagi sekolah itu sendiri dan menjadi penjejakan bagi sekolah lain. Oleh karnanya pihak sekolah nantinya akan sangat terbuka di dalam upaya pembagian informasi dan sharing masukan dari berbagai pihak agar dampak tersebut semakin berkembang dan dirasa semua pihak.

Melalui program kegiatan senam pagi yang telah berlangsung selama ini di SMPLB ini, sekolah dapat merasakan manfaat dari implementasi senam pagi tersebut. hal ini dibuktikan dari kegiatan yang tetap berlangsung sampai hampir 2 tahun ini, pihak sekolah pun mendapat respon baik selama berlangsungnya kegiatan tersebut dari siswa, wali murid dan bahkan guru sendiri.

Dampak sendiri bisa dijadikan indikator penilaian keberhasilan di dalam pelaksanaan program tersebut, sehingga juga dijadikan patokan untuk mengembangkan program tersebut. Beberapa dampak dari kegiatan terebut diantaranya: siswa merasa senang dengan kegiatan tersebut, terdapat peningkatan prestasi belajar untuk siswa dan sekolah, Kemampuan motorik atau aktifitas fisik menjadi lebih bagus, kebugaran dan kesehatn tubuh lebih baik, sehingga keseluruhan kategori tersebut sangat berpengaruh didalam peningkatan motivasi belajarya. hal ini sesuai dengang hasil wawancara dari pihak guru, siswa dan wali murid.

\section{KESIMPULAN DAN SARAN}

\section{Kesimpulan}

Dalam rancangan program (penyampiaan tujuan, penentuan sasaran, penanggung jawaban kegiatan, pemilihan bentuk kegiatan senam, pelaksanan dan pengadaan evaluasi) dijadikan acuan didalam pelaksanaan kegiatan senam sehingga dapat menyesuaikan kebutuhan siswa dan berjalan sesuai tujuan sekolah. Dari hasil wawancara, observasi dan dokumentasi yang di lakukan peneliti menunjukan bahwasannya sejauh ini proses pelaksanaan yang terdiri dari (Persiapan kegiatan senam, Pelaksanaan kegiatan senam, Hasil senam pagi dalam pembelajaran, Evaluasi) berlangsung dengan baik dan lancar. Sehingga didapat teoritisasi data yakni motivasi belajar siswa tunagrahita mampu didik dapat ditingkatkan dengan penerapan kegiatan senam setiap hari sebelum memulai pembelajaran.

Hambatan-hambatan yang selama ini dihadapi selama kegiatan senam pagi di Sekolah adalah: 1. Kondisi siwa, selanjutnya 2. Kondisi sarpras. Beberapa solusi dan alternatifnya. Pemberian solusi bagi hambatan untuk kondisi anak, pihak sekolah akan memberikan pendekatan afeksi, selanjutnya pemberian solusi bagi hambatan kondisi sarpras, pihak sekolah dan siswa memiliki cara alternatif yakni melakukan senam dengan cara manual. Beberapa dampak dari kegiatan terebut diantaranya: siswa merasa senang dengan kegiatan tersebut, terdapat peningkatan prestasi belajar untuk siswa dan sekolah, Kemampuan motorik atau aktifitas fisik menjadi lebih bagus, kebugaran dan kesehatan tubuh lebih baik. sehingga keseluruhan kategori tersebut sangat berpengaruh dalam peningkatn motivasi belajar.

\section{Saran}

Guru/penanggung jawab perlu mengupayakan pelayanan yang tepat dalam melakukan perencanaan, pelaksanaan dan evaluasi selama kegiaatan senam, sehingga kegiatan tersebut dapat berjalan sesuai harapan bersama.

\section{DAFTAR RUJUKAN}

$\begin{array}{ccc}\text { Anggraeni, } & \text { D. } & \text { Peningkatan } \\ \text { Kualitas } & \text { Pembelajaran IPS Melalui Model } \\ \text { Pembelajaran Kooperatif Tipe Course } & \text { Review } \\ \text { Horay Pada Siswa Kelas IV SD } & \text { Negeri } \\ \text { Sekaran 01 Semarang: Inproving } & \text { Social } \\ \text { Instructional Quality By } & \text { Cooperative } \\ \text { Model,Course Review Horay } & \text { Type at } & \text { Fourth }\end{array}$


SDN.Jurnal Kependidikan Dasar, (Online), [3] 1(2): 196, (http://journal/unnes.ac.id ), diakses 13 Mei 2017.

Creswell, J.W. (1998). Qualitative Inquiry And Research Design: Choosing Among Five Traditions. London: SAGE Publication.

Effendi, $\quad \mathrm{M}$. Psikopedagogik

(2009).

Pengantar Jakarta: Bumi Anak berkelainan. Aksara.

Hamdu, G. \& Agustina, L. (2011). Pengaruh Motivasi Belajar Siswa terhadap Prstasi Belajar IPA di Sekolah Dasar. Jurnal Penelitian Pendidikan. 2011, 12 (1): 83. (Online), (http://www.academia.edu ) diakse 18 Februari 2017.

I.S.A. (2016). Senam Ceria, Senamnya $A B K$ (Anak Berkebutuhan Khusus). (Online), (http://slbcgandasari-jatibarang. mysch.id), diakses 12 Desember 2016.

Ibrahim. (2015). Metodelogi Penelitian Kualitatif. Bandung: Alfabeta.

Kemdikbud. (2016). Kamus Besar Bahasa Indonesia (KBBI).

(Online), (Kbbi.web.id/motivasi.), diakses 12 Desemberr 2016.

Liyana, N., Muhariati, M. \& Rusilanti, R. (2014). Perbandingan Pola Asuh Belajar Anak Tunagrahita Mampu Didik Berdasarkan Status Ekonomi Orang Tua. JKKP: Jurnal Kesejahteraan Keluarga dan Pendidikan, (Online), 2 (1): 16, (http://journal.unj.ac.id), diakses $25 \mathrm{Mei}$ 2014.

Muhardian, M.S. (2013). Motivasi dan Disiplin Siswa Pada Mata Pelajaran Muatan Lokal (MULOK) Produktif Kelas $X$ TPHPSMK Negeri 1 Pandak Bantul. Hasil penelitian i. Yogyakarta: FT UNY. (Online), (http://eprints.uny.ac.id), diakses 12 Desember 2016.

Mujianto, G. E. (2015). Pengembangan Model Pembelajaran Penjas Adaptif Melalui Media Permainan Rainbow Flag pada s iswa tunarungu SMPLB Negeri Semarang. Journal of Physical Education, Helth and sport, (Online), 2 (1): 32-37, (http://journal. unnesa.ac.id), diakses 13 Desember 2016.

Mulyani, V.T. (2015) Memotivasi Belajar Anak Tunagrahita Mmpu didik. Dinamika Pendidikan. Jurnal pendidikan, (Online), (http://journal.uny.ac.id), diakses 12 Desember 2016.

Pandongan, E.P. (2014). Pengaruh Tari Jaranan Modifikasi bermedia VCD terhadap Kemampuan Motorik Kasar Anak Tunagrahita Ringan. Jurnal Pendidikan Khusus, (Online), ( ejournal.unesa.ac.id ).

Pradipta, R. F., \& Andajani, S. J. (2017). Motion Development Program for Parents of Child with Cerebral Palsy. Jurnal Penelitian dan Pengembangan Pendidikan Luar Biasa, 4(2).

Purnama, A. (2016). Pengaruh Senam Anak Indonesia terhadap kecepatan dan kelincahan (Studi kasus: SD Islam AL- Mubarok Surabaya). Jurnal kesehatan olahraga,(Online),(http://ejurnal. unesa.ac.i d), 4(3): diakses 27 November 2016.

Putri, S.H. (2013). Senam, (online), (http://googleweblight.com), diakses 27 November 2016.

Ragil, D.S. (2016). Tingkat Keterlaaksanaan Pembelajaran Pendidika Jasmani Bagi Siswa Berkebutuhan Khusus (Penjas Adaptif) di Sekolah Dasar Inklusi Se- kecamatan Sentolo. Skripsi. Yogyakarta: FIK UNY.

Sjarifuddin, A. (1980). Olah Raga dan Kesehatan. Jakarta: Vika press.

Soemantri, T.S. (2005). Psikologi Anak Luar Biasa. Bandung: Refika Aditama

Sugiyono. (2009). Metode Penelitian Pendidikan: Pendekatan kuantitatif, Kualitatif, dan $R \& D$. Bandung: Alfabeta.

Sugiyono. (2014). Memahami Penelitian Kualitatif. Bandung: Alfabeta.

Suryani, Y.E. (2010). Kesulitan Belajar. Dalam Jurnal Magistra, 2010, (73). (Online), (http:// www.academia.edu. ), diakses 18 Februari 2017. 